\title{
A EXPOSIÇÃO DA CARNE: CONDUTAS SEXUAIS DE CARMELITAS REFORMADOS NA AMÉRICA PORTUGUESA DO SÉCULO XVIII
}

\author{
THE EXPOSURE OF THE FLESH: SEXUAL BEHAVIORS OF \\ RETIRED CARMELITE IN PORTUGUESE AMERICA IN THE XVIII \\ CENTURY
}

\author{
André Cabral Honor \\ Doutor UFMG \\ E-mail: cabral.historia@gmail.com
}

\begin{abstract}
RESUMO: Motivado pelos constantes questionamentos que lhe são feitos sobre o comportamento dos religiosos na América portuguesa, o autor, por meio do presente artigo, analisa três casos do século XVIII que envolveram denúncias de conduta sexual de frades carmelitas seguidores da Constituição Turônica, adotada nos conventos da Cidade da Paraíba, Recife e Goiana. As peças documentais, objetos desse estudo, foram retiradas dos fundos portugueses Arquivo Nacional da Torre do Tombo e Arquivo Histórico Ultramarino. Aplicando as ferramentas teórico-metodológicas da micro história italiana, procura-se compreender esses acontecimentos não como uma parte que demonstra o todo, mas sim como um pedaço da complexidade de uma realidade maior, na qual está inserida a presença portuguesa nos trópicos. Partindo desse pressuposto teórico, pretende-se analisar as motivações que levavam esses desvios de conduta a tornarem-se objetos de denúncias às autoridades religiosas e administrativas da América portuguesa. Esses relatos adquiriam novas dimensões ultrapassando o status de boatos corriqueiros para transformarem-se em reprimendas a esses religiosos.
\end{abstract}

PALAVRAS-CHAVE: carmelitas; conduta sexual; boatos

ABSTRACT: Driven by constant questions about the behavior of regular clergy representatives in the Portuguese America, present article analyses three cases from the XVII century that involved complaints about the sexual conduct of carmelites friars that followed the Turonic Constitution adopted in the convents of Cidade da Paraíba, Recife and Goiana. The documental fragments studied in this article belong to the Arquivo Nacional da Torre do Tombo and Arquivo Histórico Ultramarino. Applying the theoretical and methodological tools of the Italian's micro history, intends to understand those facts, as pieces of broader reality in which the Portuguese presence is inserted in the tropics. Based on this theoretical conception, the article aims to analyses the motivations that transformed those misbehaviors in subjects of complaints to the religious and administrating authorities of the Portuguese America. Those reports acquired renewed significance as they grow from daily gossip to public reprimends.

KEYWORDS: carmelits; sexual conduct; gossip 


\section{Introdução}

É bastante comum ao historiador que trabalha com ordens religiosas ser questionado por acadêmicos e leigos sobre os possíveis desvios de condutas que membros do clero regular $^{1}$ possam ter cometido no passado. Existe uma curiosidade genuína sobre o comportamento dos religiosos dentro das casas conventuais, normalmente acompanhada de uma descrença sobre a retidão de seus comportamentos. Muitas vezes, essa incredulidade vem travestida de escárnio, especialmente quando o assunto é a conduta sexual desses religiosos. Sem adentrar nos meandros da psicologia e psicanálise para explicar o porquê de tamanho interesse na vida sexual do outro, ao historiador cabe perceber a temporalidade/intencionalidade dessa curiosidade.

Buscando compreender as motivações desse falatório, serão analisados três casos de denúncias de condutas sexuais de frades carmelitas da Província Reformada de Pernambuco. ${ }^{2}$ Os presentes casos serão analisados sob a perspectiva das ferramentas teórico-metodológicas micro história italiana: a redução do foco de análise, o paradigma indiciário e o esgotamento das fontes.

Esse esforço teórico em redimensionar toda a prática do ofício de historiador se projeta tanto na escolha dos "objetos de estudo", quanto na reavaliação das ferramentas analíticas necessárias para o estudo de tais objetos, agora enriquecidas com o procedimento micro-histórico a análise exaustivointensiva e a aplicação do paradigma indiciário. (AGUIRRE ROJAS, 2013, p. 28)

A própria escolha temática, os falatórios sobre os desvios de conduta sexual dos carmelitas reformados, induziu a pesquisa a uma redução do foco de análise que se substancia em apenas três casos, cujas fontes, com exceção do processo do Santo Ofício, não possuem como objeto principal a conduta sexual dos religiosos.

\footnotetext{
1 O clero regular é composto por membros de congregações religiosas monásticas, conventuais e leigas, enquanto o clero secular é formado por sacerdotes que não professam regra de nenhuma ordem religiosa.

${ }^{2}$ A Ordem Calçada de Nossa Senhora do Carmo convivia até o século XX com duas constituições distintas: a Reformada, nascida na Província de Turon na França, e a Observante, a regra original mitigada do Carmelo. A casa conventual ou província poderia decidir qual norma desejava seguir. Nas capitanias do norte do Estado do Brasil os conventos da Cidade da Paraíba (Capitania da Paraíba), Recife (Capitania de Pernambuco) e Goiana (Capitania de Itamaracá) adotaram as constituições turônicas (também chamada de reformadas ou de Estrita Observância) na segunda metade do século XVII, enquanto a casa de Olinda (Capitania de Pernambuco) permaneceu seguindo as constituições da Antiga Observância. A Província Reformada de Pernambuco é criada em 1725 como consequência dessa divisão e constituiu-se em um desmembramento dos conventos seguidores das constituições turônicas dantes pertencentes à Província Carmelita da Bahia. Sob esse assunto ver: HONOR, 2013.
} 
Buscando entender as minúcias e motivações por detrás da documentação, o paradigma indiciário serviu como ferramenta para tentar observar o que não estava explícito. "A ideia inicial é de aprender a ler os indícios, numa situação de escassez de pontos de apoio para acesso a certas realidades históricas profundas, que foram reprimidas, ocultadas, marginalizadas ou desdenhadas dentro da história e das fontes históricas." (AGUIRRE ROJAS, 2013, p. 29).

$\mathrm{O}$ esgotamento das fontes consiste nessa análise dialética entre o macro e o micro, estabelecendo relações que demonstram que o específico contém a complexidade do geral. "La investigación en este campo, dice Ginzburg, no puede ser ni la mera búsqueda de lo general en lo particular ni el énfasis dado al aislamiento, a la incomunicación, a lo irrepetible." (SERNA; PONS, 2005, p. 117).

Por meio desses paradigmas teóricos almeja-se esclarecer as motivações que trouxeram os relatos dessas condutas sexuais desviantes para o público, relacionando-os com o contexto histórico de cada situação vivenciada.

\section{O século XVIII, a vida conventual e o falatório}

Qual seria a motivação que levava as pessoas a se interessarem pela conduta sexual de religiosos no século XVIII? Com certeza, a população ordinária se deliciava com esse disseme-disse, divertindo-se à custa dos membros do clero. Por vezes, horrorizavam-se com essas condutas, porém, raramente agiam para coibi-las. ${ }^{3}$ Geralmente, esse falatório não era registrado, o que impede que os historiadores tenham acesso a essas informações, entretanto, em determinados casos, esses boatos chegavam aos ouvidos das autoridades, criando problemas para os envolvidos. O que levava as pessoas a denunciarem as condutais sexuais impróprias dos religiosos?

Esses questionamentos sobre a retidão dos frades também é consequência da própria política de arregimentação de membros que não priorizava apenas a vocação, fato que deixava o clero regular mais suscetível a escândalos dessa natureza. A presença de membros poucos virtuosos é uma problemática que acompanha os regulares desde sua origem, mas que se acentuou com a proliferação de ordens religiosas. Assim, ao longo da história dessas

\footnotetext{
${ }^{3}$ O tolerantismo religioso era uma característica da sociedade Ibérica, a despeito do forte aparelho repressor representado pelo Tribunal da Inquisição. Sobre esse assunto ver a análise de: SCHW ARTZ, 2009.
} 
instituições, verificam-se diversos casos em que a fé ou a vocação não eram os motores que motivavam uma pessoa a ingressar em uma ordem monástica. Corriqueiramente, homens e mulheres entravam para a vida religiosa por se tratar do único caminho disponível. No espaço religioso, eles podiam obter uma ascensão social que dificilmente conseguiriam no mundo profano. Preocupados mais com questões políticas e de status social, esse contexto também incitava a formação de conflitos entre as ordens religiosas.

La vida religiosa todavía ejercía una función social importante al dar cabida en los monasterios a gentes sin vocación, por puras razones sociales, aunque es verdad que miembros de la nobleza europea también abrazaron la vida claustral con auténtica vocación. La nobleza no siempre da ejemplo de vocación. La nobleza no siempre da ejemplo de vida cristiana, a pesar de que oficialmente se manifiesten como devotos cumplidores. Son clásicas las rivalidades entre las Ordenes religiosas, y de éstas con los bispos y párrocos. (MAROTO, s.d., p. 316)

Também era corrente o desejo entre progenitores de ter um membro do clero na família. Os pais enviavam filhos para conventos e mosteiros, motivados por questões políticas, ou para terem o peso de seus pecados atenuados no julgamento post-mortem como previa a "economia da salvação". ${ }^{4}$ Órfãos eram abandonados em casas do clero regular onde recebiam uma criação voltada para vida religiosa. Mulheres também eram enviadas aos conventos e mosteiros contrariando suas vontades, fossem por causa de promessas feitas pela mãe, ou para que se mantivessem resguardadas dos perigos que atentavam à honra. $\mathrm{Na}$ América portuguesa, era comum que mulheres que corressem o risco de contrair um matrimônio indesejado fossem enviadas para conventos em Portugal. ${ }^{5}$ Observando mais de perto a dinâmica social, evidencia-se que nem sempre era a devoção que conduzia uma pessoa a ingressar no clero regular.

\footnotetext{
${ }^{4} \mathrm{~A}$ economia da salvação estava diretamente ligada às questões sociais: o pobre poderia ajudar o abastado a garantir a redenção após a morte, se o rico se prestasse ao trabalho de caridade. Assim, explica-se o porquê dos testamentos durante o período colonial deixarem grandes quantias para missas, procissões, ordens e irmandades religiosas, além de trabalhos de caridade. "A condição social dos pobres que recebem assistência suscita atitudes que vão desde a comiseração até o desprezo. Eram desprezados pela própria condição de pobreza na qual se encontravam e pelas condições físicas de deficiência e doença, mas também recebiam comiseração já que eram "alvo" da boa ação de outras pessoas. Essa contradição se encontra em modos específicos da "gestão da pobreza", na economia da salvação: mesmo desprezado, o pobre pode, aceitando sua condição de pobreza, auxiliar os ricos para que esses pratiquem a caridade - a "suprema virtude cristã" - e obtenham assim a salvação. Dessa forma, os pobres também obteriam a sua própria salvação". (WALBER; SILVA, 2006, p. 32)

5 "Durante boa parte do século XVII era costume enviar filhas em idade de casar-se para conventos em Portugal, para evitar o risco de alguma ligação desastrosa. Esta prática se reduziu depois da criação do primeiro convento de freiras da colônia, na década de 1670, na Bahia, e a instalação de outros nas principais cidades durante os cinqüenta anos seguintes. Em 1734 a coroa proibiu o envio de freiras da colônia para Portugal". (LOCKHART, SCHWARTZ, 2002, p. 277)
} 
Os carmelitas estabeleceram-se como ordem religiosa no apagar das candeias do século XI. Apenas trezentos anos depois, em meados do século XV, já era uma das congregações mais expressivas, porém maculada por um estado generalizado de desregramento. Essa situação levou alguns personagens a proporem reformas em busca de uma restauração dos bons costumes. ${ }^{6}$ Como qualquer outra instituição, leiga ou religiosa, os carmelitas manifestavam a conjuntura social do período e do local em que estavam inseridos, corroborando com práticas de arregimentação de novos membros que, como já foi exposto, nem sempre atendia a interesses religiosos. Na América portuguesa, os carmelitas adequaram as práticas europeias às realidades locais, tornando o clero regular um meio de ascensão social.

Apesar de ser "proibida a admissão à Ordem de índios ou de mouros" (BAYÓN, 2001, p. 185), desde 1580 quando aportaram em Pernambuco, os carmelitas permitiram e incentivaram a entrada de pessoas nascidas na América, "receber à nossa Irmandade todos aquelles, que com piedade, e devoção a pedirem, e dar aos irmãos as letras concedidas pelo papa Clemente VII, e confirmada pelo papa Gregório XIII" (SÁ, 1727, p. 34). ${ }^{7}$ Assim a Ordem de Nossa Senhora do Carmo abria as portas de seus conventos para uma elite local, o que poderia se traduzir em benefícios futuros.

A documentação consultada resguardou apenas três notícias de desvios de conduta sexual envolvendo frades turônicos da Ordem de Nossa Senhora do Carmo. Essa pequena amostragem é ineficiente para realizar qualquer consideração mais geral sobre a virtuosidade dos carmelitas reformados na América portuguesa, pois, dificilmente teriam sido esses os únicos casos de desvios de conduta. Porém, também não é possível afirmar que os desvirtuamentos fossem demasiadamente generalizados e constituíssem regra e não exceção.

Esparsamente registradas, as condutas desviantes não pareciam ser nem tão correntes como comumente se acha, nem tão raras quanto a documentação expõe. Datada de 20 de junho de 1691, uma carta enviada do Convento de Santo Alberto ao Provincial de Portugal iniciava a exposição dos problemas enfrentados pela Reforma Turônica com a seguinte colocação:

Quando a paixão ocupa e perdomina [sic] o coração do homem falta a razão no entendimento, em estar faltando necessariamente, há de obrar

\footnotetext{
${ }^{6}$ As ordens religiosas procuravam rever seus costumes por meio de reformas que poderiam se ater apenas à casa conventual, mas também poderiam ser adotadas por outros conventos. Sobre as mais significativas reformas dentro da Ordem de Nossa Senhora do Carmo entre os séculos XV e XVII ver: SCIADINI, 1993; SMET, 1990. ${ }^{7}$ A carta supracitada envia os primeiros quatro frades carmelitas à América portuguesa na armada de conquista do Rio Paraíba comandada por Frutuoso Barbosa.
} 
iniquamente porque já então não obra o homem segundo o ditame do espirito mas segundo o demônio do mundo e da sua própria carne. (ASV, Arch. Nunz. Lisbona 89 (5), fls. 20 a 20v ). ${ }^{8}$

Os religiosos buscavam explicar as anomalias comportamentais que levavam o homem à perdição como consequências da debilidade humana frente às tentações do diabo. $\mathrm{O}$ príncipe das trevas substituía na cultura cristã a figura dos demais deuses existentes na concepção politeísta do Antigo Testamento.

O diabo esteve historicamente ligado ao monoteísmo; os primeiros hebreus não sentiram necessidade de personificar o princípio maligno, atribuindo sua influência a deidades rivais. Com o triunfo do monoteísmo, entretanto, tornava-se necessário explicar a presença do mal no mundo, já que Deus era tão bondoso: "Assim, o diabo ajudou a sustentar a ideia de uma divindade absolutamente perfeita". (SOUZA, 2011, p. 330).

Não se enganem, o homem era responsável pelos seus desvios de conduta, todavia sob influência de Satanás. Como não era possível punir o demônio ainda mais, pois já havia sido expulso da corte celestial, a alma humana sofria as consequências de sua nefasta influência.

A Igreja sabia que fraquezas e falhas dos irmãos das ordens primeira, segunda e terceira faziam parte do seu cotidiano e procurava abafá-las ou coibi-las com as armas que dispunha. As Constituições Primeiras do Arcebispado da Bahia de 1707 procuravam adequar os preceitos do Concílio de Trento ${ }^{9}$ à realidade da América portuguesa por meio da normatização e fiscalização da conduta dos membros dos cleros regulares e seculares. A vida de um religioso deveria servir de modelo à sociedade, tanto porque a boa conduta é parte indispensável da opção pelo caminho religioso, quanto porque os escândalos e desvios de conduta prejudicavam o projeto catequizador cristão que, apesar de estar diretamente atrelado ao poder temporal, frequentemente entrava em conflito com os interesses dos colonos e do Estado português.

\footnotetext{
${ }^{8}$ ASV $=$ Archivio Secreto Vaticano, Arch. Nunz. Lisbona = Archivio Nunziato Lisbona.

${ }^{9}$ O Concílio de Trento reuniu a mais alta hierarquia católica no intuito de discutir questões ligadas aos dogmas da fé e à própria atuação da Igreja na sociedade, incluindo mudanças no clero regular e o debate sobre a utilização de imagens na doutrinação, todos temas ligados à Reforma Católica. O Concílio se reuniu em três ocasiões: a primeira de 1545 a 1549; a segunda de 1551 a 1552 e a terceira de 1562 a 1563 . (HONOR, 2013, p. 57-58).
} 


\section{Primeiro caso: durante a confissão}

O primeiro caso provém de um processo inquisitorial incompleto datado de 1765 e chama atenção também por ser um escândalo sexual que envolveu adultos e crianças. Frei Ignácio de Jesus era um religioso carmelita pertencente à Província Reformada de Pernambuco que trabalhava como assistente no sertão do Panema, Freguesia de Assu na Capitania do Rio Grande. Costumava ir até a povoação de Jundiahy para visitar e participar de eventos de familiares, como assim o fez em 1754 por ocasião do casamento de uma sobrinha. Geralmente, hospedava-se na casa da viúva Dona Maria Magdalena com quem mantinha boas relações sociais.

O processo relata três casos de abusos, todavia contém o depoimento de apenas duas das vítimas. As acusações coincidem em um ponto: o frade exigia favores sexuais para conceder a absolvição dos pecados na confissão. O religioso valia-se do fato de se encontrar a sós com o confesso para praticar seu abuso sexual. Ademais, era cuidadoso ao escolher sua vítima, aproveitando-se da fragilidade social delas. Quando o ato ocorreu, dois dos acusadores eram jovens escravos e outro apenas uma criança com idade entre dez e doze anos.

Anacleta Crioula, moradora no Brejo da Taquaritinga, districto da Freguesia de Santa Anna do Bomjardim, Bispado de Pernambuco e nesse sitio ella assistia no anno de 1757. Hera escrava do Cappitao Francisco de Oliveyra, estando-a confessando dentro de huma rede, elle a sollicitara para que se metesse dentro da mesma rede, em que elle estava, e outra vez no mesmo acto de confissão a mandou que fosse a huma camarinha. (ANTT, Cota: Tribunal do Santo Ofício, Inquisição de Lisboa, proc. 10417). ${ }^{10}$

O depoimento de Anacleta está desaparecido dos autos, o que torna impossível averiguar se a escrava cedeu aos pedidos do carmelita que realizava a confissão deitado em uma rede. Instituído no século XVI, o confessionário não era o único local em que o clérigo poderia ministrar o sacramento da penitência, apesar de ser o ambiente mais recomendado pela Igreja por estar exposto na nave do templo, o que ajudava a coibir condutas desviantes. Extremamente difundido a partir das Constituiones, o confessionário não chegou a extinguir o costume de confissões em outros lugares.

${ }^{10}$ ANTT $=$ Arquivo Nacional da Torre do Tombo.

Oficina do Historiador, Porto Alegre, EDIPUCRS, v. 7, n.2, jul/dez. 2014, p. 197-220. 
Podemos dizer que o termo confessionário, entendido como o lugar de receber o sacramento da reconciliação, tem suas origens nas Constituiones escritas em 1542 pelo bispo de Verona Gian Matteo Gilberti, por motivos de ordem pastoral e disciplinar. (FRADE, 2007, P. 169) $)^{11}$

A segunda acusação vem de Luiz Poderoso de Moraes, cabra e escravo do Capitão Francisco da Costa Teixeira, morador de Jundiahy. Em seu depoimento, relata que a demora na denúncia ocorreu pela dificuldade que possuía em se deslocar, visto que era cativo. Todavia, quando soube da presença do juiz, resolveu, sob orientação de seus confessores, denunciar a conduta do frade ao visitador.

achandose o dito padre no lugar do Jundiahy já a annos, o procurara elle denunciante para confessarse por desobriga da quaresma em caza da viuva Dona Maria Magdalena, onde elle asistia e levando o dito padre a elle denunciante para huma camarinha da mesma caza onde asistia o Padre que o não absolvia sem que lhe fizece o peccado de mão, e ouvindo isto o denunciante como ignorante e rustico teve medo do que lhe dice o Padre e para que o abolveu levantose junto com o mesmo padre e lhe fez o pecado de mão, e depois disto tornou a posse de joelhos, e o padre o absolveo e como rustico e ignorante parecendolhe que estava absolvido foi elle denunciante comungar: porem doendose sempre da consciencia daquelle pecado que tinha feito ao dito padre e confessandose delle na quaresma do anno seguinte lhe dice o confessor que denunciace do dito padre ao vigario ou ao vizitador quando viesse vizitar estes certoenz porem que elle athe o prezente o não fizera por ser captivo e estar sempre morador nos certoens e vir so abayxo em occaziaõ de desobriga e que agora o faz porque vindo antes de hontem dezobrigarse nesta matriz com o padre joão Tavares da Fonseca e o adjutor della este o não quizera absolver sem que este denunciante viece denunciar o dito Padre (...). (ANTT, Cota: Tribunal do Santo Ofício, Inquisição de Lisboa, proc. 10417).

De acordo com o escravo Luiz Poderoso, ele só podia sair da fazenda localizada nos sertões por razões de desobriga, ou seja, para confessar-se durante a quaresma. Agrava-se o fato de que o escravo comungou logo após o "pecado da mão" e apesar de ter sido absolvido pelo padre, o perdão não seria válido, portanto, Luiz havia comungado em pecado. $\mathrm{O}$ depoimento vem acompanhado do relato de uma série de testemunhas que confirmaram a presença do padre na casa da viúva Dona Maria Magdalena no período alegado pelo

11 Nas palavras do próprio bispo de Verona, "Para veitar os escândalos, que as vezes podem ocorrer no ministério das confissões, estabelecemos que essas, especialmente aquela das mulheres, de agora em diante se façam sempre em lugar aberto e evidente, de modo que seja possível ver igualmente o confessor e a penitente. Além disso, estabelecemos que entre a sacerdote e a penitente exista uma 'tabulla cum fenestella, supra quam sit uma gradata seo lamina perforata', e em todas as igrejas ordenamos que sejam eretos os assim chamados confessionários.” In: FRADE, 2007, p. 169. Foi o arquiteto São Carlos Borromeu quem estabeleceu o modelo físico de confessionário mais difundido no seu livro Instructiones Frabricae et Supellectilis Ecclesiasticae de 1577. Não existem traduções para o português, porém há uma versão em espanhol: BORROMEO, 1985.

Oficina do Historiador, Porto Alegre, EDIPUCRS, v. 7, n.2, jul/dez. 2014, p. 197-220. 
denunciante. Enquanto o processo de Anacleta omite os detalhes do ato, o escravo especifica que tipo de ato teria sido cometido ao informar que foi obrigado a masturbar o frade.

A terceira acusação é a mais grave de todas. Há apenas o relato do acusador, sem outras informações sobre o processo. Seguindo o padrão de se aproveitar de pessoas em situação desprivilegiada, o frade também foi acusado por Luiz Pereira Gonzaga de ter mantido relações sexuais quando o denunciante ainda era uma criança entre dez ou doze anos de idade. $\mathrm{O}$ fato de não saber precisar sua idade à época do ato leva a crer que a vítima também se tratava de um escravo, contudo, essa informação não está explícita no documento.

\begin{abstract}
Aos vinte e tres dias do mes de abril de mil setecentos e sessenta e dois annos veio a minha presença Luiz Pereira Gonzaga morador nesta freguesia de Nossa Senhora da Piedade da Borda do Campo para donde veio padres [ilegível] da Cidade da Parahiba do Norte, Bispado de Pernambuco donde he natural e por elle me foi dito que denunciava na mesa do Santo Oficio ao Padre Frey Ignacio que por sobrenome nao [ilegível] da ordem de nossa senhora do carmo dos calçados, chamado em Pernambuco os turoens, o qual dito padre se chama por alcunha o cheira cadeados, e foi comissario dos terceiros no convento da Paraíba donde era conventual haverá quinze annos pouco mais ou menos de que sendo elle denunciante de idade de dez para doze annos indosse confessar ao convento do carmo com o dito padre frei Ignacio e este o confessou e logo mediatamente o levou para a sua cella e o solicitou para actos torpos no que elle consentio como criança o que feito o mandou logo ajoelhar para o absolver o que com effeito fez e o abolveo e que agora que tem uzo de razão, refletindo neste su[ilegível]se foi comfessar e o não querem o absolver sem que primeiro fosse denunciar, e que por essa causa o fazia e asignou comigo. (ANTT, Cota: Tribunal do Santo Ofício, Inquisição de Lisboa, proc. 10417).
\end{abstract}

Nos dois casos em que há depoimentos das vítimas, percebe-se que a conduta do padre é a mesma: colocar o fiel de joelhos e absolver os seus pecados depois dos atos libidinosos. $\mathrm{O}$ reformado ressaltava que os penitentes deveriam fazer o que lhes era pedido para que pudessem obter o perdão. Excedendo o poder que lhe era conferido como representante da Igreja, o frade aproveitava-se de sua posição privilegiada para abusar sexualmente de pessoas em situação de desvantagem. Em condições normais, e não perante o tribunal do Santo Ofício, o fato de serem escravos e não possuírem testemunhas do ato, dificultava a credibilidade de qualquer denúncia. Ciente dessa situação, o religioso se valia de forma espúria da fé dessas pessoas submetendo-as a atos libidinosos.

Acrescenta-se à denúncia um apelido que era atribuído ao religioso: "cheira cadeados". Para tentar desvendar o significado dessa expressão, recorreu-se ao dicionário de Raphael Bluteau. Nenhum dos verbetes, "cheirar" ou "cadeado", trazem alguma explicação conjunta para a expressão, pressupondo-se que ela fosse coloquial, inclusive com a 
possibilidade da alcunha ter sido criada especificamente para injuriar o frade. Entretanto, se juntarmos os dois significados, podemos desvendar o significado desse apelido.

De acordo com Raphael Bluteau, cheirar significa "tomar pelo órgão do olfato o cheiro de alguma coisa" (BLUTEAU, 1721, p. 284). Já o verbete cadeado possui duas definições, a primeira de trava de porta difundida até os dias atuais, e a segunda de brinco feminino, "Cadeado traze as mulheres nas orelhas, \& sam de huma pedra, ou muitas pequenas, e não tem pingentes, por isso tem differente nomes das arrecadas" (BLUTEAU, 1721, p. 30). No falatório cotidiano, o carmelita era comumente reconhecido por ter o costume de cheirar o pescoço das mulheres. Trazer tal apelido à tona no depoimento tinha por objetivo embasar a denúncia mostrando que era notório e público que o frade se comportava com pouco decoro com as mulheres, sendo alvo de boatos.

Talvez o religioso não fizesse diferença entre aproveitar-se de homens e mulheres para seus atos, mas o fato de ter despertado esse apelido pode indicar uma espécie de desfaçatez de sua sexualidade: ao ser reconhecido como cheira cadeados, distanciava-se de boatos envolvendo relações homossexuais, que eram extremamente mais graves perante os olhos da sociedade.

Por algum motivo a peça documental encontra-se incompleta deixando uma série de dúvidas: o restante do processo perdeu-se? O caso teria sido abafado? Teria o religioso falecido antes que pudessem interrogá-lo? Haveria fugido para evitar uma convocação do Santo Ofício? Quem seria Maria Madalegna, a viúva que hospedava o religioso em suas visitas? É provável que fizesse parte de uma elite mais abastada, pois podia se dar ao luxo de hospedar o frade oferecendo boas acomodações. Teria a mesma alguma participação nesse silêncio? São perguntas que infelizmente ainda ficam sem respostas.

Em uma primeira análise, a orientação de que as vítimas não haviam sido absolvidas parece contrariar o Concílio de Trento que estabelecia:

$<$ O Sínodo $>$ ensina também que os sacerdotes, mesmo que estejam em pecado mortal, não deixam de perdoar os pecados na qualidade de ministros de Jesus Cristo, por causa da força do Espírito Santo que eles recebem na ordenação; e que pensam de modo errado os que afirmam que os maus sacerdotes perdem aquele poder. (DENZINGER, 2007, p. 433).

Todavia, o sacramento da penitência era constituído por três matérias: contrição (dor sentida pelo penitente do pecado cometido), confissão (declaração do pecado a um sacerdote) 
e satisfação (pena designada que deve ser cumprida). ${ }^{12}$ Nos dois últimos casos, fica evidente que ambos os penitentes descumpriam a matéria da contrição, pois acreditavam que isso fazia parte do sacramento, o que invalidava a absolvição. Posteriormente, ambos perceberam o erro, e sentiram o que o Concílio chama de "uma dor da alma e detestação do pecado cometido" (DENZINGER, 2007, p. 429), o que os moveram, junto com a insistência de seus confessores, a denunciar o carmelita.

Relatando a má conduta em confissões aos seus confessores, os dois homens foram aconselhados a procurar o Tribunal da Inquisição quando o Santo Ofício fazia uma de suas visitações à América portuguesa. É improvável - mas não impossível - que houvesse qualquer espécie de conjuração contra o frei Ignácio de Jesus, visto que as vítimas moravam em capitanias distintas e provavelmente se desconheciam: a primeira residia em Pernambuco, o segundo no Rio Grande e o terceiro na Paraíba. Corrobora com essa ideia a constatação de que pelo menos dois dos denunciantes eram escravos que possuíam uma mobilidade restrita, como expresso no depoimento de Luiz Poderoso que só podia se ausentar da fazenda onde era cativo durante a quaresma. Sem nunca terem se encontrado, fica difícil conjecturar que as vítimas tivessem algum interesse em comum na vituperação do religioso.

\section{Segundo Caso: conflitos temporais e espirituais}

Em 1726, o capitão-mor de Itamaracá, José Fernandes da Silva, acusava seus desafetos, frei Miguel da Assunção e frei Manoel de São Gonçalo, de possuírem relações sexuais com uma escrava e uma jovem filha do português Benedito Soares.

Sam tam escandalozos estes dous religiozos que o dito Frey Miguel conserva nas suas terras do [ilegível] huma escrava do convento para seos uzos mundanos donde continuamente asiste alem de outras muitas que para esse effeito se guardão e padecem imquietaçoens pello não consentirem impudicamente. Com o mesmo escadallo vive o dito Frey Manoel de São Gonçalo pois tem nesta vila ajuntamento com muitas molheres e filha de certa mulher cazada com Benedito Soares natural do reyno de quem a

\footnotetext{
12 "Os atos do penitente são como que matéria deste sacramento, a saber: a contrição, a confissão e a satisfação [cân. 4]. Estes mesmos atos são requeridos por instituição divina no penitente para a integridade do sacramento e para a remissão plena e perfeita dos pecados e, por este motivo, se chamam partes da penitência." (DENZINGER, 2007, p. 429)
} 
apartou alem de outros ajuntamentos que conservam vizinhos do seo convento: (...). (AHU_ACL_CU_015, Cx. 34, D. 3164). ${ }^{13}$

Os dois frades reformados não possuíam uma boa relação com José Fernandes da Silva e vice-versa. Recém designado para a capitania de Itamaracá, o capitão-mor não tardou a entrar em conflito com os dois frades de Goiana que há 28 anos se reversavam no poder como prior e comissário do convento. De acordo com o capitão-mor, os frades do Convento de Santo Alberto interferiam no poder temporal: eram responsáveis por guardar a caixa de pelouros, levando a denúncias de adulteração de seu conteúdo. ${ }^{14} \mathrm{O}$ cofre das finanças da Capitania também estava localizado dentro do convento e uma de suas chaves ficava com o prior da casa. A desculpa utilizada para justificar a permanência do cofre e da caixa de pelouros no convento era o fato de se tratar da única edificação fortificada da vila. ${ }^{15}$ No entanto, a presença desses dois objetos na casa carmelita de Goiana evidenciava a confusão que existia na Capitania de Itamaracá entre o poder espiritual e temporal.

Frei Miguel da Assunção já havia sido expulso da vila anos antes pelo rei sob a acusação de adulterar os resultados das eleições violando a caixa dos pelouros. A volatilidade dos capitães-mores da Capitania contrastava com a permanência dos frades que habilmente souberam aproveitar essa vantagem se perpetuando no comando do convento, estabelecendo relações de compadrio com a elite local.

Em face dessa disputar de poder, o historiador deve relativizar a fala do Capitão. Afinal, seu intuito ao escrever a carta ao rei D. João V era expulsar os ditos frades da Capitania, uma punição extremamente severa e que indicava grandes desafetos entre as partes, pendendo contra os frades a condenação anterior que pesava sobre frei Miguel da Assunção. Tratava-se de uma disputa entre autoridades, em que a suposta conduta sexual dos frades foi usada como mais um elemento na vituperação dos religiosos.

A carta escrita pelo capitão-mor leva a crer que não se tratava de uma conduta recente dos frades, mas somente agora estava sendo exposta ao Rei. Isso demonstra que, além de estar

\footnotetext{
${ }^{13}$ AHU = Arquivo Histórico Ultramarino; ACL = Administração Central; CU = Conselho Ultramarino; $015=$ Seção Pernambuco; Cx = Caixa; D = Documento.

14 "O intrincado sistema eleitoral se fazia por meio de um sistema de indicações, no qual a eleição se dava através da organização de listas nominais por ordem do ouvidor da comarca, que se fazia da seguinte maneira: primeiramente, o conjunto dos "homens bons" elegia seis representantes, dividiam-nos em pares, chamados eleitores; estes, divididos em duplas, produziam as listas com os nomes dos "homens bons" que deveriam ocupar os cargos camarários. Tais listas, no total três, eram guardadas em pelouros, que eram bolas de cera, e depositadas no cofre da Câmara. No final de cada ano, um menino escolhido aleatoriamente retirava um dos pelouros, que era aberto e sua lista revelada, com os nomes contidos na mesma indicando quem seriam os ocupantes camarários do ano seguinte." (MONTEIRO, 2008, p. 2)

15 Durante o governo de Sebastião Castro e Caldas o cofre da Capitania foi remetido para a vila de Nossa Senhora da Conceição sem o consentimento do rei que ordenou o retorno do cofre ao convento carmelita de Goiana. Sobre essa querela ver: BARBALHO, 2009.
} 
atento ao falatório sobre a vida sexual, devia-se saber quando utilizar esse "conhecimento" em benefício próprio. Tornar público esses comportamentos libidinosos poderia ser o diferencial em uma decisão que favorecesse os queixosos em detrimento dos religiosos, ou seja, tratavase de uma valiosa informação que deveria ser utilizada no momento certo.

\section{Terceiro caso: disputas por poder no convento carmelita do Recife}

Em meados do século XVIII, um esparramo de grandes proporções abalou a credibilidade dos frades da reforma da Ordem de Nossa Senhora do Carmo. A denúncia veio do próprio provincial da reforma e envolvia diversos frades do Convento do Recife, além de autoridades locais. O caso foi tão grave que ocasionou o pedido de demissão de frei João de Santa Rosa, o referido provincial da reforma, em 22 de agosto de 1770, o qual alegou além da idade avançada, as "controvérsias e rebelioez que experimento em alguns dos meos súbditos" (AHU_ACL_CU_015, Cx. 109, D. 8461). Escolhido por meio de uma resolução real de 5 de agosto de 1767, o frade encontrou o Convento do Recife endividado e na eminência de um escândalo público de maiores proporções.

Apesar do envolvimento de um número maior de frades, dois carmelitas são peçaschaves para se compreender os fatos que levaram frei João de Santa Rosa a renunciar ao seu cargo: o prior do Convento do Recife, frei Jerônimo de Santo Antônio, e o ex-procurador da mesma casa, frei Francisco de Santa Rita Aragão. O histórico de ambos os religiosos foi relatado pelo provincial da reforma, no intuito de demonstrar a veracidade de suas afirmações, visto que ambos os frades possuíam um passado problemático, para não dizer obscuro.

Frei Jerônimo de Santo Antônio foi eleito procurador do Convento do Carmo do Recife em 1748. De acordo com o relato de frei João de Santa Rosa, sua gestão havia sido desastrosa, com o endividamento da casa conventual "de que rezultou apostatar da religião no anno de 1752, tempo em que era obrigado dar suas contas" (AHU_ACL_CU_015, Cx. 109, D. 8461). Não há no processo nenhum tipo de peça documental que explique os motivos que o levaram a sair da Ordem de Nossa Senhora do Carmo nessa data. Nesse mesmo ano em que abandonou a Província Reformada de Pernambuco, frei Jerônimo escreveu ao Papa Benedito XIV pedindo para ser aceito na Ordem de São Bento na França. Quatro anos depois, o frade recorreu novamente ao Papa para que pudesse retornar à América portuguesa e ser readmitido na Província Reformada de Pernambuco. De acordo com frei João de Santa Rosa, foram os

Oficina do Historiador, Porto Alegre, EDIPUCRS, v. 7, n.2, jul/dez. 2014, p. 197-220. 
escândalos praticados pelo padre em seu período com os beneditinos que o levaram a "implorar do mesmo santíssimo Papa a indulgencia para ser admittido segunda vez a mesma província perdoado das duas culpas, e restituído as honras e cargos da religião" (AHU_ACL_CU_015, Cx. 109, D. 8461). Ou seja, em algum momento frei Jerônimo de Santo Antônio foi considerado culpado. Portanto, só poderia ser readmitido na Ordem de Nossa Senhora do Carmo caso fosse perdoado, o que aconteceu por meio de um indulto papal. Dado o perdão, o frade foi readmitido na Província Reformada de Pernambuco.

Passado algum tempo sem se envolver em novos delitos - frei João de Santa Rosa fala em hipocrisia por parte do religioso - frei Jerônimo foi eleito prior do Convento do Carmo do Recife em 1762, dez anos após sua saída dos carmelitas. De acordo com o discurso de frei João de Santa Rosa, o prior recebeu avisos divinos do perigo de sua futura conduta por intermédio de uma moléstia que quase lhe custou a vida. Mesmo assim, após recuperar-se, o frade passou a infringir as normas da casa.

(...) porque com a milhora conseguida tomou para seu barato deixar o convento para morar fora com o pretexto de padecer continuados achaquez a seiz para sette annos; mas não para deixar de licensiar alguns religiozos para viverem com escândalo universal e de fazer ao convento gastos exessivos e quotidiannos com comes e bebes, convidando a muitos para estas mal consideradas funções e mandar fazer huma morada de cazas fora da praça a custa da religião para dellas se utilizar quem muito lhe parecer e pelo realce do seu proceder mostrar-se izento da obediência que professou porque as determinações que intimo como prelado maior para observância das leys, não são executadas oppondo-se quazi a todas conforme quer, e dezeja, e aggregando a sy alguns religiozos para com elle se unirem no dissoluto de sue viver sem temor e amor de Deos (...). (AHU_ACL_CU_015, Cx. 109, D. 8461).

O prior passou a viver fora do convento em uma casa na qual recebia os frades mais próximos, além de outras pessoas que não pertenciam à ordem. No seu ofício ao secretário de Estado da Marinha e Ultramar, Martinho de Melo e Castro, frei João de Santa Rosa é bem mais incisivo na vituperação de frei Jerônimo, expondo o motivo pelo qual o frade fora viver fora do Convento do Recife.

(...) ficou prior frei Jeronymo de Santo Antonio, homem sem litteratura, totalmente material, que com pretexto de achaques se deliberou a viver em huma fazenda de empréstimo perto desta vila aonde aggregando a sy os padres que constao da relação junta, por mim assignada, fizerao hum tal sequito que pondo em bloqueyo o baluarte mais forte, que tem a religião, qual he o da obediência, o tem quazi ganhado por assalto, porque querendo eu acudir a esta barbara invazao fazendo-os recolher ao convento aonde se 
remprimissem dos excessos escandalozos que cauzavai a tantos annos na referida caza de prazer, insultao de sorte os meus preceytos, (...). (AHU_ACL_CU_015, Cx. 109, D. 8461).

A acusação era grave. Frei João de Santa Rosa não explicita, mas insinua que a casa era utilizada para fins sexuais com direito a festas com comes e bebes. Para agravar a situação, o sustento dessa residência provinha da renda do Convento Carmelita do Recife, onerando e contraindo dívidas para a casa. Ademais, alguns frades compactuavam com a conduta do prior participando das folias na residência. Dentre esses religiosos estava o antigo prior do convento, padre frei João da Encarnação, cuja gestão - nas palavras de frei João de Santa Rosa - tinha sido um desastre. O reformado havia dissipado as rendas do convento promovendo festas na Igreja de Nosso Senhor do Bom Jesus, templo que não pertencia à Província Reformada, além de ter gasto dinheiro construindo edifícios para uso pessoal. Tratava-se de uma acusação extremamente grave, visto que os reformados eram proibidos de possuir bens particulares.

No mesmo tempo continuou com maiorez dispezas na factura de humas cazas de pedra e cal em huma fazenda fora da praça, para depois de completar o triênio, ir nellas morar advogando, e fazendo papeis para os seculares pelo interesse de algum estipêndio. (AHU_ACL_CU_015, Cx. 109, D. 8461).

Frei João da Encarnação era declaradamente um dos maiores inimigos de frei João de Santa Rosa, resistindo obedecer às ordens do provincial e manifestando queixas escritas em conluio com o prior do Convento do Recife.

(...) pouco satisfeitos com estas resoluções tem injustamente ordido com o padre prior e mais sequazes a iníqua dezobediencia contra a minha pessoa com assignadas e queixas synistras para me depor do cargo em que me poz sua magestade com o intuito de se entronizar pelo primeiro diffinitorio. (AHU_ACL_CU_015, Cx. 109, D. 8461).

Frei João de Santa Rosa completa a denúncia fazendo uma relação dos frades transgressores e seus supostos delitos: frei Jozé de Santa Roza havia sido expulso da Aldeia de Gramació pelo governador Luiz Diogo Lobo da Silva por ter cometido um grave delito não revelado na carta. Além disso, enquanto exercia o cargo de procurador do convento favoreceu determinados religiosos com mais e melhores vestimentas, infringindo a regra da igualdade entre os religiosos estabelecida pela Estrita Observância; frei Feliz de Santa Clara, que estava vivendo fora do convento exercendo atividades ilícitas não reveladas; frei Ignacio do Paraizo,

Oficina do Historiador, Porto Alegre, EDIPUCRS, v. 7, n.2, jul/dez. 2014, p. 197-220. 
acusado de ser pouco obediente às regras; frei Manoel de Jezus, sacristão-mor, que já havia sido punido pelo provincial por diversas vezes devido a sua vida licenciosa e seu letargo; frei Sylvestre de Santa Roza e frei Pedro de São Thomaz, acusados de se aliarem ao prior do convento em suas imorais ações.

Completava a lista, frei Francisco de Santa Rita Aragão, que também era um dos grandes desafetos do provincial. Alguns anos antes, o frade havia sofrido uma condenação por um furto de dez mil cruzados, porém recorreu ao rei e teve seu delito perdoado. O documento revela mais adiante que o frade fugiu do convento após a acusação e deve ter retornado apenas com o perdão promulgado pelo rei.

\begin{abstract}
A este padre depois de cometter aquelle grande crime do furto de dez mil, tantos cruzados, feito ao vigário desta paroquial - Feliz Machado Freyre, pelo qual apostatou da ordem da secretaria de estado de 14 de abril de 1766 que a vossa excelência faço prezente pelo documento em publica forma do governador e capitam general Conde de Villa Flor com o qual veio perdoado e absolvido por sua magestade, o trattey respeitando com o mais profundo acatamento o real decreto, como amorozo pay, persuadindo-me teria emenda para o futuro (...). (AHU_ACL_CU_015, Cx. 109, D. 8461).
\end{abstract}

A guerra de ofensas entre o provincial e o religioso se acirrou após uma acalorada discussão dentro da cela do frei João de Santa Rosa, que terminou com gritos de ambas as partes, os quais atraíram os demais frades do convento que saíram de seus aposentos para ver o que acontecia.

(...) mas abuzando logo do soberano perdão e da minha clemência se rebellou contra a minha pessoa por não querer condescender com os seus depravados intentos, alterando vozes na minha cella e fora della deante de religiozos graves da mesma província por este e outros motivos o despedi da minha graça. (AHU_ACL_CU_015, Cx. 109, D. 8461).

A partir de então, a troca de ofensas e as manipulações políticas internas para denegrir a imagem um do outro se tornaram explícitas para a comunidade carmelita. Frei Francisco de Santa Rita possuía uma inimizade declarada com o subprior do Convento do Recife, frei José de Santa Rita, que era aliado do provincial da reforma, frei João de Santa Rosa. Para acirrar os ânimos, frei Francisco de Santa Rita era amigo do então prior do Convento do Carmo do Recife, frei Jeronimo de Santo Antonio, grande desafeto do provincial.

Os ânimos andavam tão açulados na casa conventual que em 22 de agosto de 1770, frei Francisco de Santa Rita desapareceu de sua cela deixando uma carta e uma petição que explicavam os motivos da fuga. Os documentos foram encontrados pelo próprio provincial na 
presença de mais seis frades do convento e mostram uma situação que vai além do exposto por frei João de Santa Rosa.

Dois meses antes de sua fuga, em 22 de junho de 1770, um encontro foi marcado entre frei Francisco de Santa Rita e frei José de Santa Rita, o qual resultou na prisão do subprior no convento, seis dias após o malfadado encontro. Infelizmente não é possível saber o real motivo que levou à detenção do religioso. Porém, a documentação deixa transparecer que frei José de Santa Rita andava armado, portanto o motivo de sua prisão pode ter sido devido ao porte de arma branca ou por uma suposta agressão ao seu irmão conventual. Seguem as palavras do frei Francisco de Santa Rita.

(...) o padre Frei Jose de Santa Ritta subprior do mesmo convento no dia 22 de junho no qual se fisera o dito subprior muitas vezes violadas das leys do mesmo monarca, em andar de costume armado de huma faca de ponta, arma proibida pelas ditas leis, com a qual accomettera ao suplicante esperando-o de cazo pensado para lhe tirar a vida diante de pessoas seculares que presenciarão o cazo estando o suplicante no tido convento residindo por ordem de sua magestade e que alem disso proferira o dito Frei Subprior as temerárias palavras de que não fazia caso nem temia a El Rey, (...). (AHU_ACL_CU_015, Cx. 109, D. 8461. Petição não entregue de autoria do frei Francisco de Santa Rita).

A acusação se agravou devido à ofensa que o subprior teria feito ao monarca. Não há como saber se a afirmação era verdadeira ou não, todavia constitui uma maneira eficaz de persuadir o rei à punição de frei José de Santa Rita, pois dá margem para a sua caracterização como insurgente contra o reino português. Pouco tempo antes, frei Francisco de Santa Rita já havia feito uma denúncia ao ouvidor da Capitania de Pernambuco na qual questionava a fidelidade de seu companheiro religioso ao rei, chamando o provincial de inconfidente.

E o que mais he que venho eu dado a denuncia no juízo da inconfidência e estando o ouvidor por mim taes voltas lhe tem dado que seguidamente parese tãobem já hoje faz as vezes do provincial pois lhe revelou a dita denuncia, e o provincial tem dado voltas e revoltas sobre isso (...). (AHU_ACL_CU_015, Cx. 109, D. 8461. Carta não entregue de autoria do frei Francisco de Santa Rita).

Sentindo-se injustiçado pelo ouvidor, José de Santa Rita ressalta a acusação de que os seus desafetos é que eram infiéis ao rei. Essas denúncias reverberavam com maior força perante o monarca, principalmente após a Guerra dos Mascates, que havia sacudido a 
Capitania de Pernambuco depois da desobediência à ordem régia de emancipação da vila do Recife. $^{16}$

A versão propalada pelo provincial fala de uma armação de frei Francisco de Santa Rita contra o dito subprior do convento.

Vindo-se desta destituído procurou ardilozo a amizade do referido prior do Reverendo Frei Jeronymo de Santo Antonio e seus sequazes para derrubar a muitos com suas intrigas e malevolências pelas quaes chegou a experimentar do subprior do convento do Recife o Padre Frei Joze de Santa Rita sênior hum anojado encontro para o intimar. Deste pretexto se valeu para maquinas traições e levantar falsos testimunhos, como tem por costume, pondo-me de inconfidente ao nosso soberano e tão ao subprior como consta da petição e carta incompleta que as achey na sua cella na prezença de vários religiozos. (AHU_ACL_CU_015, Cx. 109, D. 8461).

Em sua carta, frei Francisco revela o temor que tinha de ser assassinado pelo então subprior do Convento do Carmo do Recife, frei José de Santa Rita. Acusa-o de contrariar as ordens reais ao andar armado com uma faca de ponta e insinua que frei João de Santa Rosa seria o mandante de seu assassínio.

(...) vendo o padre provincial que o reo estava convicto e confessiado de huns tais crimes que mereciao pennas gravíssimas, com effeito como esta desfeita que se me fez, foi por conselho ordem e mandado do padre provincial pois não posso suppor outra cousa pelo vêlo todo empenhado na liberdade do preso amedrontando os religiosos para não jurarem a verdade e prometendo vingar-se na visita delles. (AHU_ACL_CU_015, Cx. 109, D. 8461. Carta não entregue de autoria do frei Francisco de Santa Rita. Grifo meu).

Com a detenção de frei José de Santa Rita, o provincial empenhou-se em libertá-lo. Preso na sala de custódia do convento - localizada estrategicamente ao lado de uma capela para que o detento pudesse participar do ofício divino - o subprior foi libertado pelo provincial, sem pedir autorização ao prior do convento, responsável pelo encarceramento do religioso. Frei Francisco de Santa Rita descreve sua versão dos fatos, execrando as ações do provincial, acusando-o de conspirar contra sua vida, mas também de ameaçar os demais religiosos que depusessem contra o subprior.

\footnotetext{
${ }^{16}$ As chamadas sublevações em Pernambuco - que somente adquiririam o título de Guerra dos Mascates após o romance de José de Alencar no século XIX - constituíram-se de uma série de conflitos na Capitania de Pernambuco, consequência direta do desastroso governo do capitão-mor Sebastião de Castro e Caldas, cujo ápice foi a destruição do pelourinho da vila do Recife, recém emancipada de Olinda. Sobre esse conflito ver: MELLO, 2003.
} 
(...) fizera tão pouco apreço o dito M. Reverendo Padre Provincial desta representação que não só não deo o mínimo castigo e reprehenção ao dito subprior se não que o mandou absolver das censuras em que tinha incorrido, motivo que obrigou ao dito Reverendo Padre Prior a fazer encarcerar ao dito subprior depois de seis dias com auxilio de braço militar e proceder a sumario de testemunhas pelo referido insulto: e estando o processo em termos de ser sentenciado e sabendo o dito Mestre Apostólico Padre Provincial que se achavão provados os crimes do dito subprior e que por eles merecia pennas gravíssimas conforme as duas contituiçoens, sem embargo de ter intimadado a muito relgiozos para não jurarem a verdade antes que se proferisse sentença se resolveo ao mais precipitado arrojo e dispotismo de ir ao cárcere no dia 16 de julho associado de alguns religiozos seos facionarios, e partidistas a soltar o dito subprior de poder absoluto, sem consetimento attenção nem beneplácito do seo juiz competente e prior local accompanhando ao mesmo subprior athe a sua cella com vivas e festejos e com notável escândalo dos seculares desta republica tanto porque já a todos erão notórias as referidas culpas como porque se acharão muitos prezentes na occasião da soltura em razão da festividade de nossa senhora do Carmo que nesse dia se celebrava. (AHU_ACL_CU_015, Cx. 109, D. 8461. Petição não entregue de autoria do frei Francisco de Santa Rita ).

Antes de ir libertar o preso, frei João de Santa Rosa foi até o governador para que o mesmo pudesse acompanhá-lo na soltura. Todavia, esse não quis se intrometer afirmando que o caso estava fora de sua jurisdição e aconselhando o frade que recorresse ao responsável pelo seu encarceramento, o prior do Convento do Carmo do Recife, frei Jerônimo de Santo Antônio.

(...) se mandou a petição ao padre prior, o padre prior não a quis soltar, e o padre provincial chamando ao carcereiro com obediencia o fez abrir as portas do cárcere e soltar ao padre sem intervir vontade do prior local violencia que nunca se vio em religião alguma. (AHU_ACL_CU_015, Cx. 109, D. 8461. Carta não entregue de autoria do frei Francisco de Santa Rita).

O já explicitado desafeto que existia entre o prior e o subprior constituía um real empecilho para a libertação de frei José de Santa Rita. Independente da culpabilidade do réu, o prior dificilmente aceitaria que o subprior fosse solto. Sem ter a quem recorrer, o provincial foi pessoalmente até a custódia e ordenou ao frade carcereiro que abrisse a porta, fato que foi acompanhado por exultações de comemoração de alguns frades. As últimas palavras de frei Francisco de Santa Rita são fortes e expõem a enormidade da crise que viveu o Convento do Carmo do Recife na segunda metade do século XVIII.

(...) isto não he religião, nem he nada, he huma casa de loucos, de foragidos e de perversos, ou já estive em termos de me botar para esse mundo a buscar outra vês a magestade porque vejo que entre estes malvados poucos dias terei de vida pois mais em huma ou mais em outra volta me ham de tirar a 
vida. (AHU_ACL_CU_015, Cx. 109, D. 8461. Carta não entregue de autoria do frei Francisco de Santa Rita).

Após o seu desaparecimento, perde-se o rastro de frei José de Santa Rita. Para o provincial, a sua fuga é prova da culpa que o religioso possuía. No fim, é impossível averiguar quem estava certo na contenda. A balança da culpa pesa para o lado do prior e de seus aliados, em especial de frei José, pelos antecedentes criminais relatados. Contudo, também não foi possível ir mais a fundo na vida do provincial e do subprior para saber se os mesmos possuíam um passado idôneo. Há de se considerar um interesse político de frei José de Santa Rita em ver seu superior, frei José de Santo Antônio, destituído de seu cargo, pois, de acordo com a hierarquia do convento, o subprior assumiria o cargo de prior em caso de vacância.

O processo não apresenta nenhuma decisão do rei ou do Conselho Ultramarino. A fuga de frei José de Santa Rita e o pedido de exoneração do cargo de provincial feito por frei João de Santa Rosa devem ter esfriado os ânimos no convento fazendo com que a contenda se resolvesse internamente, tornando desnecessária a intervenção de autoridades portuguesas.

$\mathrm{O}$ caso relatado evidenciou os conflitos internos por poder que existiam nas casas conventuais, além de revelar a presença de condutas inadequadas que transitavam dentre desvios de comportamento sexual, furtos e tentativas de assassinatos. Não obstante uma crise tão grave não era regra nos conventos da Província Reformada de Pernambuco, e se eram corriqueiras essas confusões, permaneceram restrita à Província, passando desconhecidas pelo Conselho Ultramarino ou pelas visitações do Santo Ofício. ${ }^{17}$

A denúncia da conduta sexual dos frades, que chegaram a sustentar uma casa onde aconteciam as festas libidinosas, é mais um elemento dentro de uma série de graves acontecimentos que envolveram os carmelitas reformados do Recife. A forma como a acusação é exposta, direta, porém não explícita, sem esmiuçar qual seria essa conduta prazerosa, indica um certo cuidado do denunciante em expor publicamente esse comportamento que poderia se virar contra a Ordem Carmelita como um todo.

Não há porquê descartar uma motivação moral do provincial em sua denúncia sobre a casa, entretanto, imbricado a essas questões de conduta, há também a vontade de vituperar com ardor frei Jerônimo de Santo Antônio e seus aliados, que no fim, constituíram o motivo pelo qual frei João de Santa Rosa pediu demissão do seu cargo de prior. A junção dessas duas motivações podem explicar porque o religioso decidiu expor esse comportamento mesmo

\footnotetext{
${ }^{17}$ Infelizmente a documentação da Província Reformada de Pernambuco se perdeu quase que por completo, devido ao abandono dos arquivos no convento do Recife e ao terremoto de Lisboa de 1755 que destruiu todo o arquivo do convento carmelita da cidade. Poucas peças documentais ainda podem ser encontradas no arquivo privado do convento do Recife e também no convento carmelita de Belo Horizonte.
} 
sabendo que isso denegria os frades turônicos indistintamente. E quando o fez, foi com bastante discrição, escolhendo bem as palavras, que poderiam ter sido mais incisivas e diretas. Seu comedimento mostra que, mesmo em uma situação caótica, o frade pensou na Província como um todo e na mancha que sua fala poderia agregar aos turônicos caso um escândalo dessa magnitude fosse comprovado.

Nesse último caso, revela-se o painel de um complexo jogo político de disputa por poder dentro da Província Reformada de Pernambuco. Durante a querela, foram expostas as más condutas no intuito de manchar a reputação de determinados frades para que assim suas alegações tivessem mais fôlego perante as autoridades competentes.

\section{Considerações finais}

Na denúncia feita ao Santo Ofício, a exposição era movida pelo sentimento de culpa das vítimas que foram orientadas pelos seus confessores a procurar o Tribunal. Não há indícios que houvesse falatórios públicos, ao menos que os confessores tivessem quebrado o voto de silêncio. Nesse caso, a descrição do ato fazia parte do próprio sistema de denúncia inquisitorial que esmiuçava a conduta malquista. No segundo relato, o falatório cotidiano sobre a conduta pouco virtuosa de membros do clero regular constituiu-se em uma ferramenta política de persuasão que o capitão-mor utilizou para ratificar as razões pela qual pediu a expulsão dos frades, o que explica porque não mediu suas palavras na descrição da exposição da conduta. No terceiro caso, os próprios religiosos se acusam em uma disputa interna por poder, e, por essa razão, há uma certa parcimônia na descrição, pois o corporativismo administrativo da Ordem, nos moldes da administração laica portuguesa na América, tornava a conduta de um como parte de um todo que apesar da sua autonomia era indissociável do resto. Independente dos motivos que levavam à exposição das condutas sexuais era a própria Ordem Carmelita como instituição que sofria o revés pela conduta desvirtuada de alguns de seus membros.

Longe de representarem uma totalidade de comportamentos, os três casos relatados demonstram a complexidade de uma sociedade que se constituiu na América portuguesa.

Portanto, o verdadeiro núcleo do procedimento micro-histórico italiano, o que está no centro de sua preocupação, não é somente o micro nem somente 
o macro, mas a totalidade dessa complexa dialética entre os níveis ou escalas macro-históricas e micro-históricas. E isso, para além das formas tradicionais de enfocar estes níveis sociais, dentro de uma perspectiva dialética, que pressupõe a interpenetração mútua, em que o macro está presente no micro e o micro contém o macro, sem eliminar suas diferenças específicas, (...). (AGUIRRE ROJAS, 2012, p. 109)

Para o historiador, esses casos funcionam como um microcosmo de um universo cultural religioso que ora se move pelo espírito religioso, como nas denúncias feitas contra frei Inágcio de Jesus, ora por interesses laicos, no caso das acusações relatadas pelo capitãomor José Fernandes da Silva, e ora por uma mescla indissociável entre fé e poder, como é possível averiguar no esparramo descrito por frei João de Santa Rosa. Em todos os casos, a honra do religioso, e da Ordem Carmelita, estava posta em jogo. Nesse contexto, a exposição de escândalos sexuais e financeiros poderia constituir o diferencial na ascensão ou derrocada do prestígio de um religioso, ou, até mesmo, de uma casa conventual.

\section{REFERÊNCIAS BIBLIOGRÁFICAS}

AGUIRRE ROJAS, Carlos Antonio. Micro-história italiana: modo de uso. Trad. Jurandir Malerba. Londrina: Eduel, 2012.

BARBALHO, Luciana de Carvalho. Capitania de Itamaracá poder local e conflito: Goiana e Nossa Senhora da Conceição (1685-1742). 126 f. Dissertação (Mestrado em História) Universidade Federal da Paraíba, João Pessoa, 2009. Captado em:

$<$ http://www.cchla.ufpb.br/ppgh/2009_mest_luciana_barbalho.pdf $>$. Acesso em: $02 \mathrm{mar}$. 2012.

BAYÓN, Balbino Velasco. História da Ordem do Carmo em Portugal. Lisboa: Paulinas, 2001.

BLUTEAU, Raphael. Vocabulario portuguez \& latino: aulico, anatomico, architectonico ... v. 2.. Coimbra: Collegio das Artes da Companhia de Jesus, 1721.

BORROMEO, Carlo. Instrucciones de la fábrica y del ajuar eclesiásticos. Introdução, tradução e notas de Bulmaro Reyes Coria. Ciudad del México: Imprenta Universitária/UNAM, 1985.

DENZINGER, Heinrich. Compêndio dos símbolos, definições e declarações de fé e moral. Tradução José Marino Luz. São Paulo: Paulinas: Loyola, 2007.

FRADE, Gabriel. Arquitetura sagrada no Brasil: Sua evolução até as vésperas do Concílio Vaticano II. São Paulo: Loyola, 2007. 
HONOR, André Cabral. O verbo mais-que-perfeito: uma análise alegórica da cultura histórica carmelita na América portuguesa. Belo Horizonte: Fino Traço, 2013.

LOCKHART, James; SCHWARTZ, Stuart B. A América Latina na época colonial. Trad. Maria Beatriz de Medina. Rio de Janeiro: Civilização Brasileira, 2002.

MAROTO, Daniel de Pablo. Historia de la espiritualidad cristiana. 2 ed. Madrid: Editorial de Espiritualidad, s.d..

MELLO, Evaldo Cabral de. A fronda dos mazombos: nobres contra mascates, Pernambuco, 1666-1715. 2. ed. São Paulo: Editora 34, 2003.

MONTEIRO, Lívia Nascimento. Distinção social nos trópicos: as eleições na câmara de São João Del Rey em meados do século XVIII. In: ENCONTRO DE HISTÓRIA DA ANPUH RIO, XXIII, 2008, Niteroi. Anais do XXIII Encontro de História da Anpuh - Rio. Niteroi: ANPUH, 2008. Captado em: <http://encontro2008.rj.anpuh.org/resources/ content/anais/1212866921_ARQUIVO_ResumoeTextoAnpuh-RIO.pdf>. Acesso em: 09 abr. 2014.

SÁ, Frei Manoel de. Memórias históricas da Ordem de Nossa Senhora do Carmo da Provincia de Portugal. Lisboa Oriental: Offycina Joseph Antonio da Silva, 1727.

SCHWARTZ, Stuart B. Cada um na sua lei: tolerância religiosa e salvação no mundo atlântico ibérico. Trad. Denise Bottman. São Paulo: Companhia das Letras; Bauru: EDUSC, 2009.

SCIADINI, Frei Patrício. O Carmelo: História e Espiritualidade. São Roque: Carmelitanas, 1993.

SERNA, Justo; PONS, Anaclet. La historia cultural: autores, obras, lugares. Madrid: Akal, 2005.

SMET, Joaquín. Los carmelitas: Historia de la Orden del Carmen, las reformas. En busca de la autenticidad (1563-1750). Madrid: Biblioteca de autores cristianos, 1990.

SOUZA, Laura de Mello e. O diabo e a terra de Santa Cruz: feitiçaria e religiosidade popular no Brasil colonial. 2 ed. São Paulo: Companhia das Letras, 2011.

WALBER, Vera Beatriz; SILVA, Rosane Neves da. As práticas de cuidado e a questão da deficiência: integração ou inclusão?. Estudos de psicologia, n. 23, v. 1, Campinas, jan./mar. 2006, p. 29-37. Captado em: <http://www.scielo.br/pdf/estpsi/v23n1/v23n1a04.pdf> Acesso em: 30 nov. 2014. 


\section{LISTAGEM DAS FONTES PRIMÁRIAS E ARQUIVOS}

Archivio Secreto Vaticano, Archivio Nunziato Lisbona, 89 (5), fls. 20 a 20v. Localizado na Cidade do Vaticano, Itália. Acesso restrito, pesquisa somente mediante autorização prévia. Não há disponibilização online.

Arquivo Histórico Ultramarino; Administração Central; Conselho Ultramarino; Seção Pernambuco; Caixa 109; Documento 8461 / Caixa 34, Documento 3164. Localizado em Lisboa, Portugal. Também disponível através do Projeto Resgate Barão do Rio Branco: $<$ http://www.cmd.unb.br/resgate_index.php $>$.

Arquivo Nacional da Torre do Tombo, Cota: Tribunal do Santo Ofício, Inquisição de Lisboa, proc. 10417. Localizado em Lisboa, Portugal. Uma pequena parte do seu acervo pode ser encontrada no sítio oficial do arquivo: <http://antt.dglab.gov.pt/>.

ARTIGO ENVIADO EM: 20/06/2014

ACEITO PARA PUBLICAÇÃO EM: 27/10/2014 